- Strategic Planning Committee of the NSTL at the Ministry of Science and Technology in Beijing. He told the meeting that the NSFC, NSTL and NSL will support the government's request to make research papers open immediately after publishing, and that implementation policies should follow soon. He expects funders to push all researchers in China to follow suit.

Zhang told the Open Access 2020 conference, convened by Germany's Max Planck Society, that any idea that open access has little traction in China is misleading. Since 2014, funders and research institutions in China have encouraged - and funded scientists to publish papers in open-access formats, and to archive manuscripts openly online. But, he added, much of China's scientific output is locked behind paywalls. "NSFC funds about 70\% of Chinese research articles published in international journals, but China has to buy these back with full and high prices," he says. "This is simply wrong — economically and politically."

He called on publishers at the meeting to start negotiating transformative deals with Chinese library consortia without delay. Such 'read and publish' agreements, which have been struck by a number of European national library consortia, and which the University of California system is also hoping to negotiate, cover the subscription costs of paywalled journals, but also allow corresponding authors at eligible institutions to publish their work openly in those journals.

\section{CLEAR SIGNAL}

China's commitment to ending subscription publishing took publishers at the meeting by surprise. "This is the first clear signal I received from China on this matter," said Daniel Ropers, chief executive of Springer Nature. "We were under the impression that open access isn't quite as urgent an issue in China as it is in Europe and the United States. If it is indeed, we are more than happy to engage."

Springer Nature, he says, already offers a broad range of open-access journals and would consider developing the portfolio further in all disciplines of science. But he says a viable solution is still needed for highly selective subscription journals, including Nature, to satisfy Plan S. (Nature's news team is editorially independent of its publisher, Springer Nature.)

As it stands, the plan would bar scientists funded by participating agencies from publishing their work behind a paywall after 2020, unless they can also archive the accepted manuscript immediately online with a liberal publishing licence (which few subscription journals permit). Many subscription journals do offer an open-access option, but Plan S will fund publication by that 'hybrid' route in only some cases, and will review this policy in 2023.

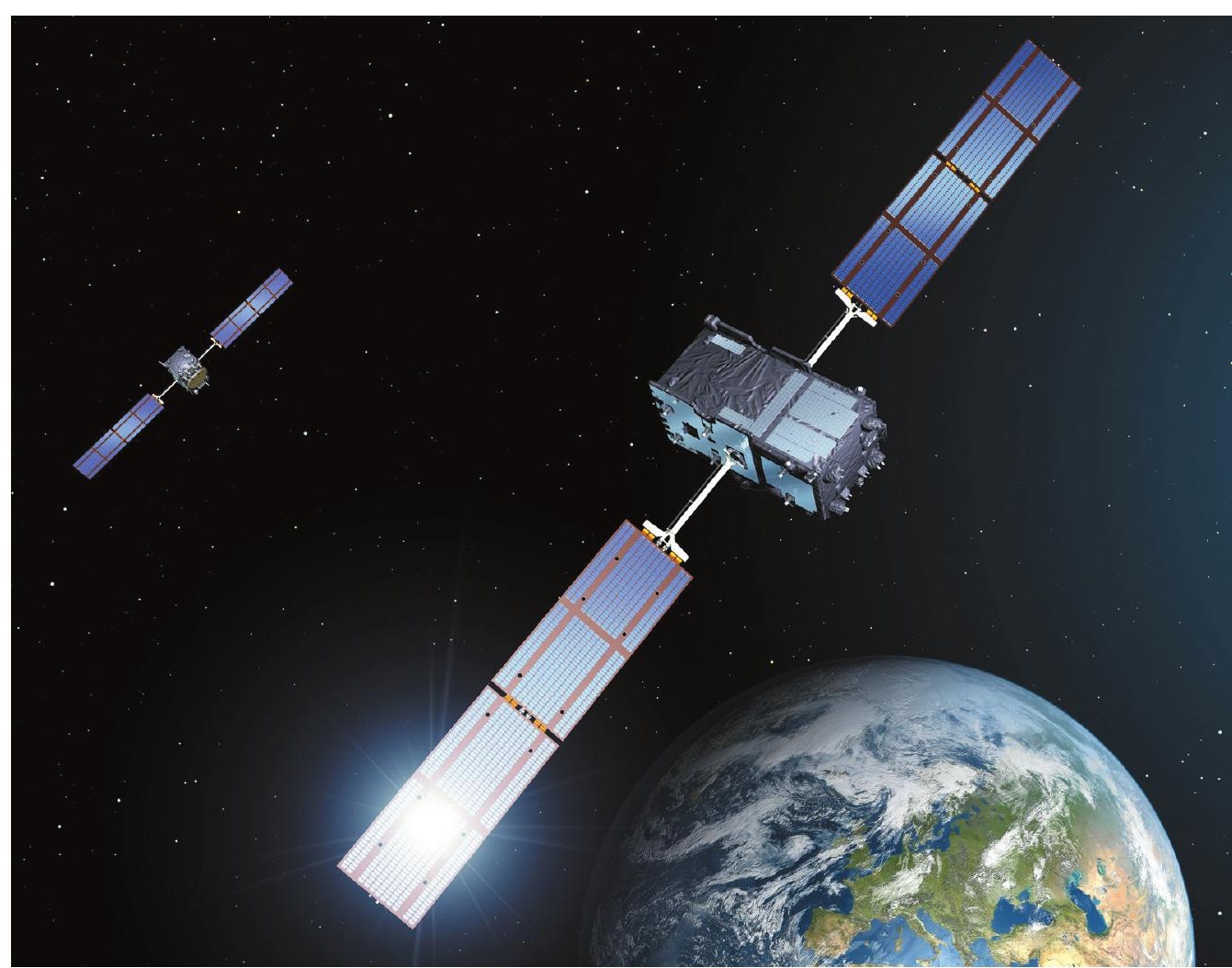

The European Union's Galileo network (artist's impression) is a global satellite-navigation system.

BREXIT

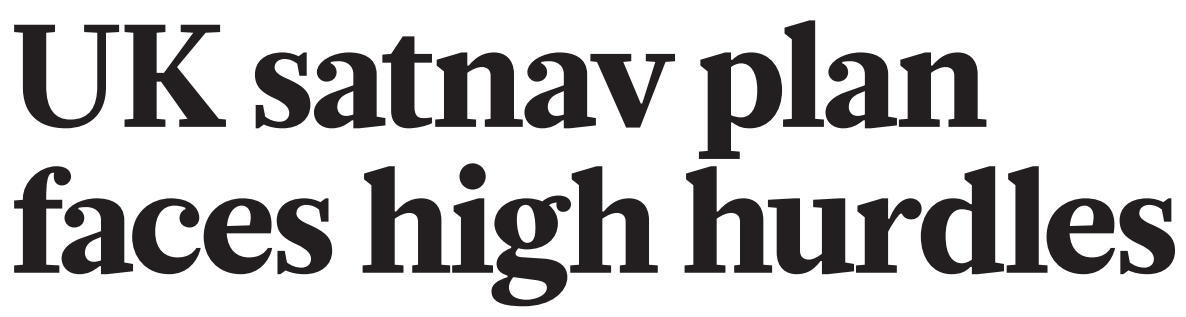

\section{BY DECLAN BUTLER}

$\mathrm{T}$ The row over Britain's attempt to stay fully involved in the European Union's global satellite-navigation (satnav) system, Galileo, after it departs the bloc, is back in the headlines after science minister Sam Gyimah cited it in his resignation statement last month. Gyimah's resignation came after the country's Prime Minister Theresa May had said that the UK government would end talks with the EU on Galileo, and would instead consider building its own global satnav system for use after Brexit.

That idea was first floated by the government in May, but many experts have dismissed it as expensive, unnecessary and even unfeasible - the lack of available space on the radio spectrum to run such a system could be a show-stopper.

Nature digs into the dispute.

\section{What did the science minister say about} Galileo?

Gyimah said that the EU's superior hand in negotiations over the programme convinced him that Britain would fare badly in future Brexit negotiations on other issues, including research.

What is Galileo, and why is it so important? Galileo is one of four global satnav systems, which provide myriad civilian, scientific and defence services. The others are the US Global Positioning System (GPS), Russia’s Global Navigation Satellite System (GLONASS) and China's BeiDou, which will be fully operational in 2020. The EU started the Galileo programme in 1999 to break its dependence on the GPS and GLONASS.

The Galileo constellation - comprising 26 satellites - was completed this July; a nearcomplete constellation began beaming down 
signals free of charge to smartphones and other receivers in December 2016.

Researchers also combine signals and use them in an array of scientific applications, including the monitoring of movements in Earth's crust and for the study of the atmosphere.

The Galileo programme is building another 12 satellites as in-orbit spares and to replace older machinery. It is also starting to build a next-generation system. The EU opened the first of the tenders for building these craft in June. Total costs for the Galileo programme are estimated at around $€ 13$ billion (US $\$ 15$ billion) to $€ 15$ billion to the end of 2020 .

\section{How would Brexit change the United}

Kingdom's participation in Galileo, and why is the UK government unhappy?

Brexit would have no effect on the availability of Galileo signals to scientists and other UK citizens - the service is freely available to anyone on the planet.

But a UK-based company, Surrey Satellite Technology in Guildford, a subsidiary of the aerospace giant Airbus, built all the satellites made so far (although many components, such as the satellites' atomic clocks, are sourced from suppliers in Europe).

However, the EU has already effectively excluded UK companies from bidding for the lucrative tender for the next-generation satellites. The British government has complained that this treatment is unfair, given its contributions so far.
After Britain leaves the bloc on 29 March 2019 , it will also automatically stop being involved in the defence-related aspects of the Galileo programme - something the government was pushing to stay a part of.

\section{What are Galileo's defence applications?}

The system's secure service, scheduled to be fully operational by around 2026, will be restricted to government-authorized users, including the

"Spending
$£ 3$ billion to
$£ 5$ billion on a
UK system would
be grotesquely
wasteful."
military and essential services such as energy supplies and telecoms. The signals are encrypted to stop interference or malicious jamming.

The United King-

dom has been closely involved in the secure system's development. It had argued that this close participation, and its significant role in EU defence matters, mean it should be given special treatment that would allow it a full role in the inner workings of Galileo's defence aspects. But EU rules do not allow a non-member state to be involved in the development of such security aspects.

The United Kingdom said that this is unacceptable, leading May to say on 1 December that the government would abandon plans to use Galileo for defence and critical national infrastructure. She also confirmed that the United Kingdom was looking at options for building its own global system.

\section{Is that proposal credible?}

It might be technically feasible, say experts Britain has the science and engineering skills to build such a system - but it probably isn't affordable. Widely cited estimates put the construction cost at somewhere between $£ 3$ billion (US $\$ 4$ billion) and $£ 5$ billion. That doesn’t include the running costs, which amount to about $€ 800$ million a year for Galileo. For comparison, the UK space agency's budget this year is $£ 402$ million, and Britain's defence research budget will be about $£ 1.9$ billion next year.

"Spending $£ 3$ billion to $£ 5$ billion on a UK system would be grotesquely wasteful," says Robert Massey, deputy executive director of the UK Royal Astronomical Society in London.

And even if Britain were to build its own system, there could be a crucial technical limitation: the lack of available space on the radio spectrum.

\section{What's the issue with the radio spectrum?}

The four existing global satnav systems already take up the part of the spectrum allocated for satellite navigation by the International Telecommunication Union (ITU), says Alexandre Vallet, head of the ITU's Space Services Department in Geneva, Switzerland. Squeezing in a new global system might require novel radiosignal designs that don't interfere with other systems, says Vallet. And these would need to be endorsed by international agreements - so it would be a challenge, he says.

\section{'Super' DNA targeted by drugs}

\section{DNA segments that amplify gene activity might represent a new form of gene regulation.}

\section{BY HEIDI LEDFORD}

$\mathrm{E}$ xperimental cancer treatments that harness souped-up segments of DNA called super-enhancers to activate genes are working their way to the clinic for the first time. But scientists are still debating how these elements work - and whether they represent a fundamentally new way of regulating genes.

Preliminary data suggest that screening for a particular super-enhancer can identify people with acute myeloid leukaemia who might benefit from a drug called tamibarotene. The data were presented by the drug's maker, Syros Pharmaceuticals, on 2 December at a meeting of the American Society of Hematology in San Diego, California. And on 15 November, the company debuted data from another preliminary trial, in which people with solid tumours were given a drug that targets a protein called CDK7. Laboratory tests have shown that inhibiting this protein can reduce the activity of a super-enhancer that has been linked to some cancers (E. Chipumuro et al. Cell 159, 1126-1139; 2014).

The trials are the first attempts to target super-enhancers to treat human disease. But it is still unclear whether these DNA segments are truly stronger versions of better-known gene-regulating sequences called enhancers. "The word is still out," says Lothar Hennighausen, a geneticist at the US National Institute of Diabetes and Digestive and Kidney Diseases in Bethesda, Maryland. "I'm inclined to think that they are not."

Researchers have long known that enhancers are important for regulating when and how strongly genes are expressed. But in 2013, a group found that some enhancers, called super-enhancers, cluster together near genes that help to determine a cell's unique identity - whether it becomes a mammary or a muscle cell, for instance (D. Hnisz et al. Cell 155, 934-947; 2013).

Super-enhancers seem to be particularly important in embryonic stem cells, and they are sometimes hijacked by cancer cells to drive the aberrant gene activity that fuels tumour growth.

And super-enhancers also attract unusually large numbers of the proteins required to activate the genes they control. These clusters of enhancers and proteins might allow cells to tightly regulate important genes, ensuring that they will be turned on exactly when needed and in precisely the right amount, says Christopher Vakoc, who studies gene expression at Cold Spring Harbor Laboratory in New York and has advised Syros.

"It's all about precision," says Vakoc. "When the cell goes to that much effort to control a gene, it's because the product of that gene is pivotal in biology."

Although mammalian cells have 